\title{
Impacts of invasive trees on alpha and beta diversity of temperate forest understories
}

\author{
Marcin K. Dyderski $\mathbb{B} \cdot$ Andrzej M. Jagodziński $\mathbb{B}$
}

Received: 16 April 2020/Accepted: 19 September 2020/Published online: 28 September 2020

(C) The Author(s) 2020

\begin{abstract}
Despite good recognition of distributions and spread mechanisms of the three most invasive trees in Europe (Prunus serotina, Quercus rubra and Robinia pseudoacacia), their impacts on forest biodiversity are unevenly recognized. Most studies cover only taxonomic alpha diversity, and only a single study included functional and phylogenetic diversity. Using a set of 186 study plots in western Poland we assessed the impacts of these invasive tree species on the alpha and beta taxonomic, functional and phylogenetic diversity of understory vascular plants. Alpha diversity was higher in $R$. pseudoacacia forests and lower in $Q$. rubra forests compared to mature native forests. Compared to non-invaded plantations and forests, alpha diversity was higher in $P$. sylvestris plantations invaded by $P$. serotina, but lower in invaded nutrient-poor $P$. sylvestris forests. Alien
\end{abstract}

Electronic supplementary material The online version of this article (https://doi.org/10.1007/s10530-020-02367-6) contains supplementary material, which is available to authorized users.

M. K. Dyderski $(\bowtie) \cdot$ A. M. Jagodziński

Institute of Dendrology, Polish Academy of Sciences, Parkowa 5, 62-035 Kórnik, Poland

e-mail: mdyderski@man.poznan.pl

A. M. Jagodziński

Faculty of Forestry and Wood Technology, Department of Game Management and Forest Protection, Poznań University of Life Sciences, Wojska Polskiego 71c, 60-625 Poznań, Poland species richness was higher and beta diversity was lower in forests invaded by $P$. serotina or $R$. pseudoacacia than in non-invaded forests. In contrast, beta diversity was higher in $Q$. rubra forests than in native forests. We proved that invaded forests differed from non-invaded forests in species composition, but not always with decreased alpha and beta diversity. Impacts of particular invasive species also depended on the reference ecosystem properties (here mature native forests, which did not always have the highest biodiversity), which is a source of inconsistency in previous studies, usually referring to single native ecosystem types.

Keywords Phylogenetic pairwise distance . Functional richness - Exotic trees - Biodiversity · Species richness - Biotic homogenization $\cdot$ Ecoevolutionary naivety

\section{Introduction}

Invasive alien species are considered one of the most important threats to native biodiversity (Richardson 1998; Mack et al. 2000; Vilà et al. 2011). However, impacts of particular invasive species differ with invader quantity (Kumschick et al. 2015; Pearse et al. 2019), the ability for habitat transformation (Corenblit et al. 2014; Aerts et al. 2017; Castro-Díez et al. 2019) 
and recipient community susceptibility to invasion (Lonsdale 1999; Davis et al. 2000). Therefore, both ecological success and impacts on native ecosystems by invasive species are highly context-dependent (Kumschick et al. 2015; Dyderski and Jagodziński 2019a; Sapsford et al. 2020).

Despite numerous studies on the impacts of invasive alien species, most of them focused on the taxonomic diversity of invaded ecosystems (Olden et al. 2018). Even in cases of relatively wellrecognized invasive species in regions with good data coverage, recognition of various aspects of biodiversity affected by invasive species is uneven. Review of studies on impacts of the three most frequent invasive tree species in European woodlands (Wagner et al. 2017): Prunus serotina Ehrh., Quercus rubra L. and Robinia pseudoacacia L. (Table 1) revealed that among 71 impacts found, only one considered functional diversity (Chabrerie et al. 2010) and onephylogenetic diversity (Piwczyński et al. 2016). We also found 17 impacts on proportions of specialist and generalist plant species connected with the filtering of particular traits. In general, invaded stands hosted fewer forest specialists (Woziwoda et al. 2014; Staska et al. 2014; Šibíková et al. 2019) and more alien species (Halarewicz and Żołnierz 2014; Montecchiari et al. 2020). However, in specific conditions trends were different: e.g. in Berlin R. pseudoacacia forests hosted fewer alien plant species in the understory than native Betula pendula Roth. forests (Trentanovi et al. 2013), and in riparian forests $P$. serotina and $R$. pseudoacacia supported the presence of forest specialists, as these invasive trees occurred in lessdisturbed sites within the study area (Terwei et al. 2016). Therefore, knowledge about the impacts of the most frequent invasive trees in European woodlands (Wagner et al. 2017) is scarce and requires a unified assessment regarding multiple types of native ecosystems.

We aimed to assess the impacts of three invasive tree species on species composition and taxonomic, phylogenetic and functional alpha and beta diversity of understory vascular plant communities, in relationship to the mature native forest ecosystems. We hypothesized that the invasive tree species studied will differ in impacts on species diversity and its mechanisms. In detail, we assumed that invasive tree species, due to habitat modification and increased availability of nutrients, will not decrease alpha diversity, but will decrease beta diversity of understory vegetation, by promoting generalist species. We also assumed that diversity of forest specialist species will be more affected by invasive trees than other species.

\section{Materials and methods}

\section{Species studied}

We studied the effects of three invasive trees: Prunus serotina, Quercus rubra and Robinia pseudoacacia, introduced from the eastern part of North America. All

Table 1 Number of studies comparing particular aspects of understory plant diversity between alien- and native-species dominated forests or along invasive species abundance gradients. Details and references-see Table S1

\begin{tabular}{|c|c|c|c|c|c|c|c|c|c|}
\hline \multirow[t]{2}{*}{ Biodiversity aspects analyzed } & \multicolumn{3}{|c|}{$P$. serotina } & \multicolumn{3}{|l|}{ Q. rubra } & \multicolumn{3}{|c|}{ R. pseudoacacia } \\
\hline & Positive & $\begin{array}{l}\text { No } \\
\text { impact }\end{array}$ & Negative & Positive & $\begin{array}{l}\text { No } \\
\text { impact }\end{array}$ & Negative & Positive & $\begin{array}{l}\text { No } \\
\text { impact }\end{array}$ & Negative \\
\hline $\begin{array}{l}\text { Taxonomic alpha diversity- } \\
\text { Shannon index }\end{array}$ & 0 & 0 & 2 & 0 & 0 & 2 & 1 & 2 & 3 \\
\hline $\begin{array}{l}\text { Taxonomic alpha diversity-species } \\
\text { richness }\end{array}$ & 0 & 3 & 4 & 0 & 0 & 4 & 2 & 5 & 5 \\
\hline Taxonomic beta diversity & 0 & 0 & 0 & 0 & 0 & 0 & 1 & 2 & 1 \\
\hline Alien species richness & 3 & 1 & 0 & 0 & 1 & 0 & 1 & 2 & 5 \\
\hline $\begin{array}{l}\text { Specialists-generalists (impact on } \\
\text { specialists) }\end{array}$ & 3 & 0 & 3 & 1 & 0 & 4 & 1 & 0 & 7 \\
\hline Functional diversity & 0 & 0 & 1 & 0 & 0 & 0 & 0 & 0 & 0 \\
\hline Phylogenetic alpha diversity & 0 & 0 & 0 & 0 & 0 & 0 & 0 & 0 & 1 \\
\hline
\end{tabular}


of them were introduced as ornamental species in the 17 th century and then used in forestry and for other uses (Starfinger et al. 2003; Cierjacks et al. 2013; Dyderski et al. 2020). Due to the high decomposition rate of leaf litter, $P$. serotina was widely used as a soil improver (Aerts et al. 2017; Horodecki and Jagodziński 2017). P. serotina usually forms a dense shrub layer, decreasing light availability (Muys et al. 1992; Halarewicz and Żołnierz 2014; Jagodziński et al. 2019). Q. rubra is a tall tree, growing faster than native oaks and producing slowly decomposing leaf litter, while also decreasing light availability (Dobrylovská 2001; Woziwoda et al. 2019; Dyderski et al. 2020). $R$. pseudoacacia is a pioneer, fast-growing tree species, increasing soil fertility due to its ability to fix nitrogen (Rice et al. 2004; Cierjacks et al. 2013).

\section{Study design}

We used a set of 189 study plots (200 $\mathrm{m}^{2}$ rectangles) established in Wielkopolski National Park (WNP; W Poland; $52^{\circ} 16^{\prime} \mathrm{N}, 16^{\circ} 48^{\prime} \mathrm{E} ; 7584$ ha) and described in detail in previous studies (e.g. Dyderski and Jagodziński 2018, 2019b). WNP includes various types of temperate forests, with mean annual temperature of $8.4{ }^{\circ} \mathrm{C}$ and mean annual precipitation of $521 \mathrm{~mm}$, for the years 1951-2010. Study plots are systematically arranged, with nine plots in each of 21 blocks (Fig. 1), designed to assess natural spread of the invasive tree species studied. In the center of each study block is a plot within a monoculture of the invasive species studied (in the case of $P$. serotina $-P$. sylvestris monocultures with understories dominated by $P$. serotina). Then, four additional plots were set up off of the N, S, E and W sides of the central plot, nearly outside the alien species monoculture, and another set of four plots, located $30 \mathrm{~m}$ away from each of the four additional plots. Three study plots (due to systematic design) occurred in non-forest ecosystems and were excluded from analyses (thus final $n=186$ ).

We classified study plots into nine forest types (Fig. 2), similarly as in Dyderski and Jagodziński (2020). This division reflects the phytosociological variability of invaded and uninvaded vegetation. Fagus sylvatica dominated forest refers to Deschampsio flexuose-Fagetum Schröder 1938, an acidophilous beech forest with scarce understory. Quercus petraeadominated forest refers to Calamagrostio
arundinaceae-Quercetum petraeae (Hartman 1934) Scamoni et Pass. 1959 acidophilous oak forest, with co-dominance of Pinus sylvestris in the overstory. Quercus-Acer-Tilia forest refers to Galio sylvaticiCarpinetum (R. Tx. 1937) Obverd. 1957, a fertile $Q$. petraea, Acer platanoides, A. pseudoplatanus, and Tilia cordata dominated forest. $Q$. rubra dominated forests refers to former $Q$. rubra plantations, replacing natural $Q$. petraea and Quercus-Acer-Tilia forest vegetation, while Robinia pseudoacacia dominated forest refers to former $R$. pseudoacacia forests replacing Quercus-Acer-Tilia forests. We divided Pinus sylvestris forests into two groups: poor (occupying mainly mesic sites of Leucobryo-Pinetum (Libbert 1933) W. Mat 1962 and Calamagrostio arundinaceae-Quercetum petraeae), and plantation (on nutrient-rich soils, which replaced Galio sylvaticiCarpinetum). In each of them we distinguished a variant invaded by $P$. serotina, which spontaneously colonized both types of forests.

We classified plots with more than 500 ind. ha ${ }^{-1}$ of $P$. serotina $>1.3 \mathrm{~m}$ tall, as invaded. We also distinguished $Q$. rubra or $R$. pseudoacacia forests, with $>$ $25 \%$ (mostly $>75 \%$ ) of basal area, which originated from former plantations.

\section{Data collection}

Within each study plot we recorded vascular plant species and cover using a modified (Barkman et al. 1964), 9-degree Braun-Blanquet scale (r-single individuals, +- few individuals $<1 \%$ cover, $1-<5 \%$ cover, $2 \mathrm{~m} \leq 5 \%$ cover but numerous individuals, $2 \mathrm{a}-$ $5-15 \%$, 2b-15-25\%, 3-35-50\%, 4-50-75\%, 5 $\geq 75 \%$ ) in July of each study year (2015-2018). Then we averaged them at the study plot level. As study plots were permanently marked, we assumed no relocation bias (Verheyen et al. 2018). We also reduced bias connected with observer effect (Lepš and Hadincová 1992) by conducting all field observations by the same author (MKD). Taxonomic nomenclature follows GBIF (2019), as suggested by Seebens et al. (2020) to standardize taxonomy. In total, we found 262 species.

In each plot we assessed the number of species in six guilds: archaeophytes (alien species introduced before 1500, 14 species), neophytes (alien species introduced after 1500, 36 species), all alien species 


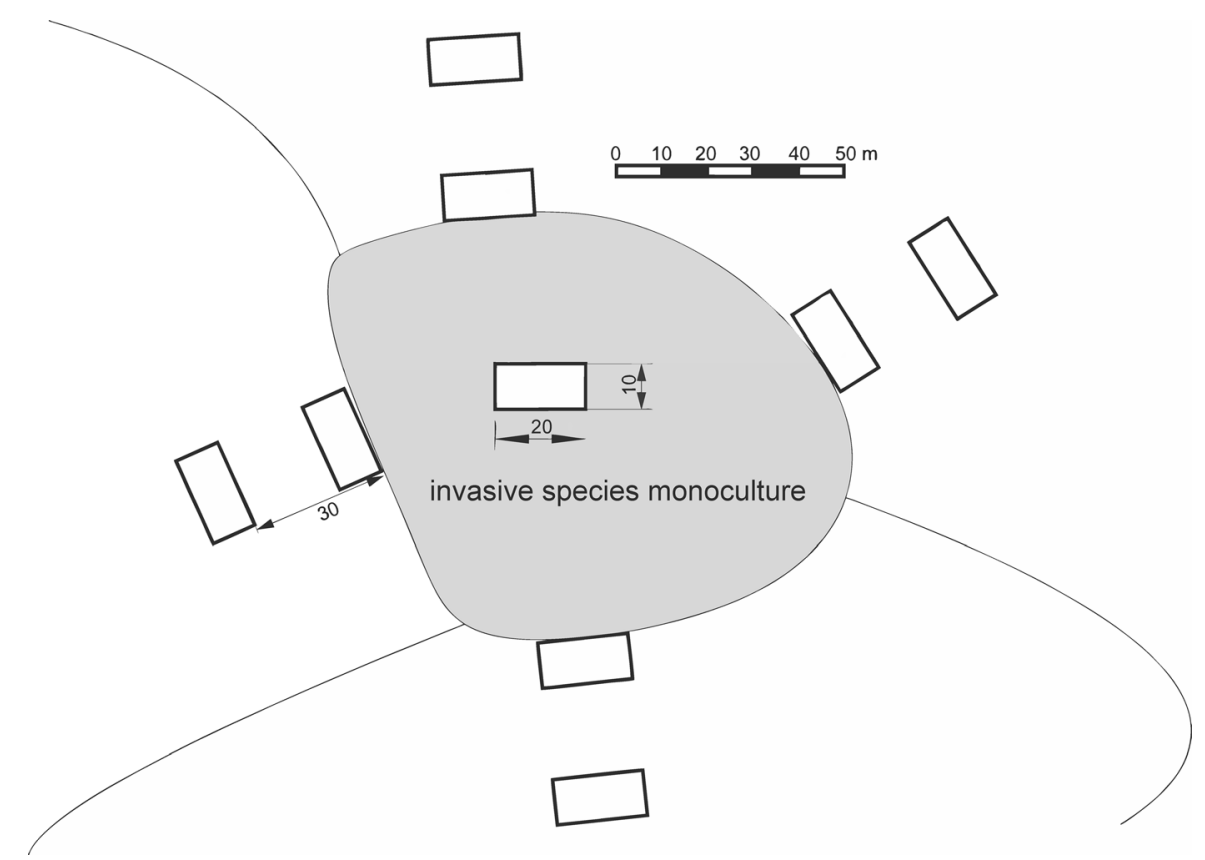

Fig. 1 Schematic arrangement of the study plot blocks (21 blocks, each composed of nine plots). Adapted from Dyderski and Jagodziński (2019c), for the spatial arrangement of forest types within block see supplementary material in Dyderski and Jagodziński (2020)

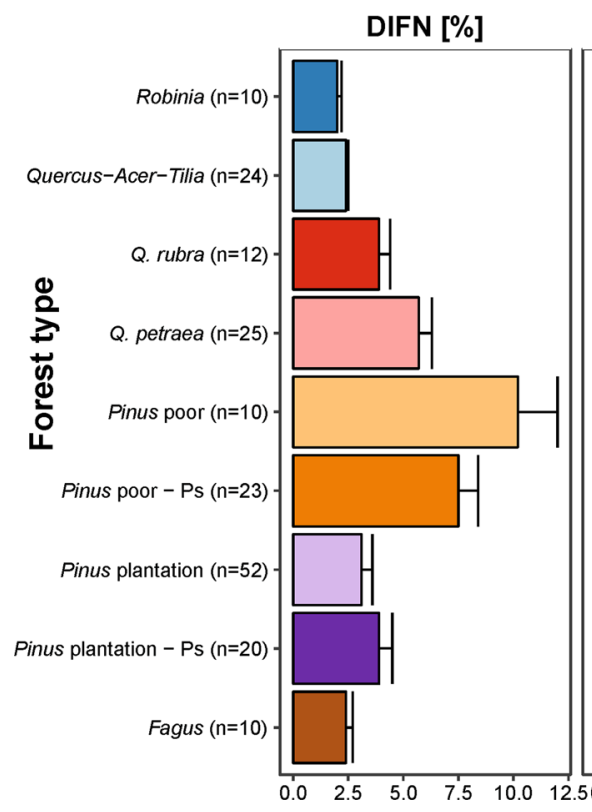

Fig. 2 Mean ( + SE) light availability (DIFN, a fraction of open skylight availability at $0.5 \mathrm{~m}$ height), soil C:N ratio and $\mathrm{pH}$ (in $\mathrm{H}_{2} \mathrm{O}$ ) by forest type (Fagus-Fagus sylvatica dominated forest, Pinus plantation-Pinus sylvestris forests in fertile sites, Pinus plantation-PS-P. sylvestris plantation invaded by Prunus serotina, Pinus poor-P. sylvestris forest in poor sites, Pinus
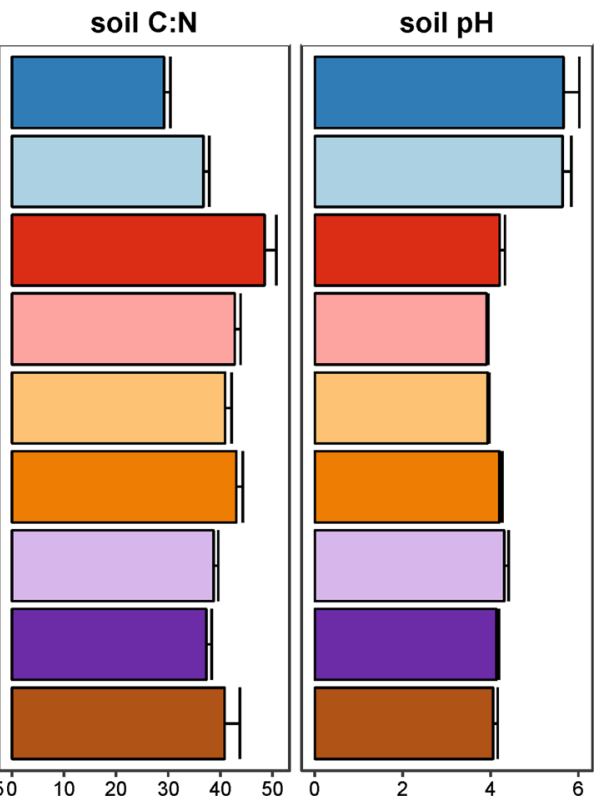

poor-PS- $P$. sylvestris forest in poor sites invaded by $P$. serotina, $Q$. petraea-acidophilous $Q u e r c u s$ petraea-dominated forest, $Q$. rubra-Q. rubra dominated forests, Quercus-Acer-Tilia-Q. petraea, Acer platanoides, A. pseudoplatanus, Tilia cordata dominated fertile forest, Robinia-Robinia pseudoacacia dominated forest). For details see Dyderski and Jagodziński (2020) 
(sum of archaeophytes and neophytes, 50 species), forest species (see below, 62 species), forest edge and ruderal species (72 species) and ancient forest indicator species (AFIS, 50 species; Table S2). We distinguished alien species, with division into archaeophytes and neophytes according to the national alien plant species checklist (Tokarska-Guzik et al. 2012). We also distinguished guilds of forest species (members of Querco-Fagetea Br.-Bl. et Vlieger 1937, Vaccinio-Piceetea Br.-Bl. in Br.-Bl. et al. 1939 and Quercetea roboris-petraeae $\mathrm{Br}$.-Bl. in $\mathrm{R}$. Tx et al. 1943 nom. mut. classes) and forest edge and ruderal species (Artemisietea vulgaris Lohmeyer et al. in $\mathrm{R}$. Tx. 1950, Epilobietea angustifoli R. Tx. et Preising in R. Tx. 1950, Stellarietea mediae R. Tx. et al. in R. Tx 1950 and Trifolio-Geranietea Th. Müller 1962 classes) according to phytosociological review (Ratyńska et al. 2010). We also distinguished AFIS, as a guild of forest specialists, sensitive to forest ecosystem transformation (e.g. Peterken 1974; Orczewska 2009; Dyderski et al. 2017). We distinguished AFIS according to the Dzwonko and Loster (2001) checklist.

We obtained a phylogenetic tree for species present in the study plots from the megatree included in the V.phylo.maker package (Jin and Qian 2019) and we obtained functional traits (Table 2) from LEDA (Kleyer et al. 2008), BIEN (Enquist et al. 2016), BiolFlor (Klotz et al. 2002) and Pladias (Wild et al. 2019) databases, and ecological indicator values from Ellenberg and Leuschner (2010). Due to incomplete trait data, we decided to impute missing data rather than omit them in analyses (see Pyšek et al. 2015) by random forest-based imputation (Penone et al. 2014), implemented in the missForest package (Stekhoven and Bühlmann 2012). We enforced the predictive power of imputation models by phylogenetic eigenvectors (Diniz-Filho et al. 1998), obtained using the PVR package (Santos 2018). The first 15 phylogenetic eigenvectors covered $59.4 \%$ of the variation in phylogenetic distances among species. Normalized root mean squared error of imputed traits was 1.054 for continuous predictors and the proportion of falsely classified categorical variables was 0.401 .

Calculation of diversity indices

We investigated the effects of alien tree species on native understory vegetation. We analyzed three aspects of native species diversity-taxonomic, phylogenetic and functional at two levels-alpha (withinsite) and beta (among sites). We quantified taxonomic alpha diversity using species richness and Shannon's diversity index, calculated using the vegan package (Oksanen et al. 2018). We quantified phylogenetic diversity using Faith's phylogenetic diversity (PD; i.e. the sum of phylogenetic tree branch lengths, representing all species present in the community) and mean pairwise phylogenetic distance (MPD) between species within the community. We calculated them using the PhyloMeasures package (Tsirogiannis and Sandel 2016). We quantified functional diversity by functional richness (FRic), expressing the quantity of plant functional types present in a community and functional dispersion (FDis), expressing the size of community species traits hypervolume within the functional trait space (Mason et al. 2005; Laliberté and Legendre 2010; Pla et al. 2011). These two indices were calculated using the FD package (Laliberté et al. 2014).

We used Jaccard's dissimilarity index to assess taxonomic, functional and phylogenetic beta diversity, as this metric was the most frequently used in previous studies on biotic homogenization (Olden et al. 2018). Taxonomic beta diversity was based on a presenceabsence matrix, functional diversity - on the volume of convex hull intersections in a multidimensional functional space (extracted from principal coordinates analysis from species traits of a Gower dissimilarity matrix) and phylogenetic diversity - on PD; all of these were calculated using the betapart package (Baselga et al. 2018). For each beta diversity index we calculated overall value, nestedness and turnover (Baselga 2010). This allowed us to explain the importance of nestedness (presence of core species) and turnover (species replacement) in shaping dissimilarities among particular forest types.

\section{Data analysis}

We analyzed data using R software (v. 3.5.3; R Core Team 2019). We assessed species composition of study plots (using square root transformed data) by detrended correspondence analysis (DCA; Hill and Gauch 1980), implemented in the vegan package (Oksanen et al. 2018). We decided to use DCA as a method dedicated to data across long environmental gradients (over $3 \mathrm{SD}$ units), due to the gradient 
Table 2 Traits used in the study, their ranges, variation coefficient (CV) and completeness

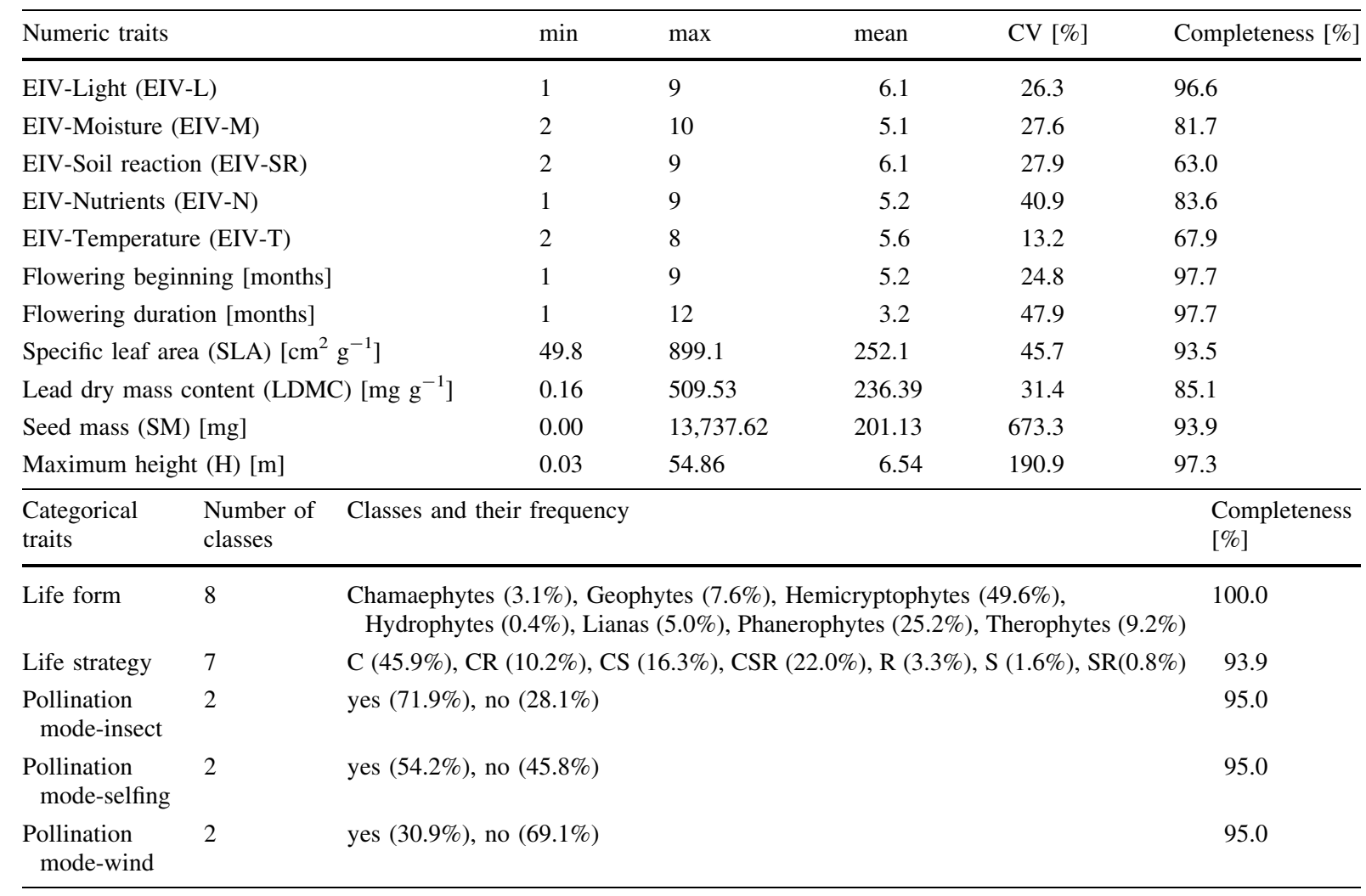

detrending procedure included in the analysis. We assessed differences in alpha diversity and richness of particular species guilds using generalized linear mixed-effects models (GLMMs), accounting for dependencies among plots within blocks by the random intercept. We assumed Gaussian distributions of Shannon index, PD, MPD, FRic and FDis and Poisson distribution of species richness. In cases of differences between beta-diversity indices we used linear models. We assessed the impacts of forest type on response variables by ANOVA. Although models could reveal differences among forest types with p-values $<0.05$, via Tukey's posteriori tests we applied a single-step adjustment of p-values, to account for multiple hypothesis testing. Single-step adjustment decreases the probability of committing Type I error (i.e. rejection of the true null hypothesis), and also accounts for correlations among variables tested (Bretz et al. 2011). We ensured a lack of problems with zero-inflation and overdispersion of models using tests provided by the DHARMa package (Hartig 2020).

\section{Results}

Understory vegetation species composition

Composition of understory vascular plant species revealed the main gradient along DCA1 axis, from the least fertile $P$. sylvestris forests to $P$. sylvestris plantations, $Q$. petraea, $Q$. rubra and $F$. sylvatica forests to the most fertile Quercus-Acer-Tilia and $R$. pseudoacacia forests (Fig. 3). Invaded forest types were separated from non-invaded along DCA2 axis (mixed-model ANOVA, numerator $\mathrm{df}=1$, denominator $\mathrm{df}=169.07, F=12.872, p=0.0004$ ). Points representing invaded forest types occurred in the upper part of the ordination space. Most of the AFIS 




Fig. 3 Detrended Correspondence Analysis of understory species composition on the study plots $(n=186)$. Italicized labels represent species scores and are abbreviations of species names (e.g. Vaccmyrt = Vaccinium myrtillus), red label indicates alien species, green label-ancient forest indicator species. Only species with cover sum within the whole dataset $>20 \%$ were plotted (57 of 262). Forest types: Fagus-Fagus sylvatica dominated forest, Pinus plantation-Pinus sylvestris forests in

scores occurred in the lower part of the DCA space, while most of the alien species were in the upper part.

We found the highest number of AFIS and forest species in Quercus-Acer-Tilia and R. pseudoacacia forests while the lowest-in $F$. sylvatica forests (Table 3, Fig. 4). Non-invaded poor $P$. sylvestris forests hosted $24.8 \%$ more forest species than $P$. serotina invaded forests (despite lack of significance fertile sites, Pinus plantation-PS- $P$. sylvestris plantation invaded by Prunus serotina, Pinus poor-P. sylvestris forest in poor sites, Pinus poor-PS- $P$. sylvestris forest in poor sites invaded by $P$. serotina, $Q$. petraea-acidophilous Quercus petraea-dominated forest, $Q$. rubra-Q. rubra dominated forests, Quercus-AcerTilia-Q. petraea, Acer platanoides, A. pseudoplatanus, Tilia cordata dominated fertile forest, Robinia-Robinia pseudoacacia dominated forest

revealed by posteriori tests). We also found lower AFIS and forest species numbers in $Q$. rubra than $Q$. petraea forests. We found the highest number of edge and ruderal species in R. pseudoacacia forests, $29.8 \%$ more than in Quercus-Acer-Tilia (despite lack of significance revealed by posteriori tests). The lowest number was in F. sylvatica and $Q$. rubra forests. We found the most alien species, both archaeophytes and

Table 3 Analysis of variance for ancient forest indicator species (AFIS), forest, edge and ruderal, alien, archaeophyte and neophyte species number in forest types studied, estimated using Poisson GLMMs

\begin{tabular}{lllccccc}
\hline Response & Variable & df & Sum of Squares & Mean Square & F & Pr $>$ F) & Block random effects SD \\
\hline AFIS & Forest type & 8 & 443.9000 & 55.4900 & 5.7650 & $<0.0001$ & 0.253 \\
Forest species & Forest type & 8 & 919.6000 & 114.9500 & 9.9310 & $<0.0001$ & 0.255 \\
Edge and ruderal species & Forest type & 8 & 1226.0000 & 153.2900 & 7.1650 & $<0.0001$ & 0.331 \\
Alien species & Forest type & 8 & 265.7000 & 33.2200 & 5.6840 & $<0.0001$ & 0.269 \\
Neophytes & Forest type & 8 & 154.3000 & 19.2800 & 5.6540 & $<0.0001$ & 0.241 \\
Archaeophytes & Forest type & 8 & 38.0500 & 4.7560 & 4.1520 & 0.0001 & 0.512
\end{tabular}




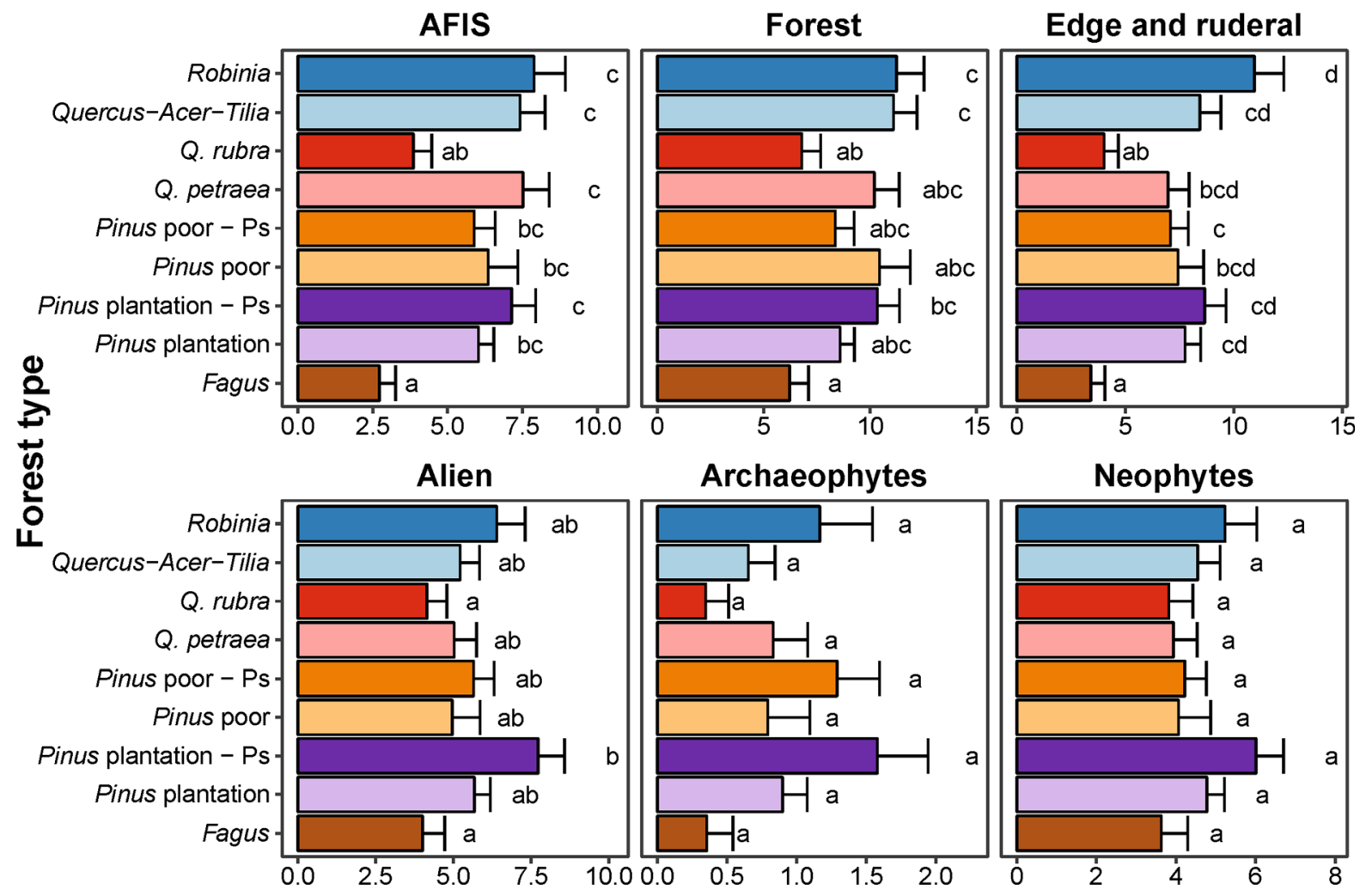

Fig. 4 Mean ( + SE) number of ancient forest indicator species (AFIS), forest, edge and ruderal, alien, archaeophyte and neophyte species in forest types studied (Fagus-Fagus sylvatica dominated forest, Pinus plantation-Pinus sylvestris forests in fertile sites, Pinus plantation-PS- $P$. sylvestris plantation invaded by Prunus serotina, Pinus poor-P. sylvestris forest in poor sites, Pinus poor-PS-P. sylvestris forest in poor sites invaded by $P$.

neophytes, in $P$. serotina invaded $P$. sylvestris forests. Despite the lack of differences revealed by posteriori tests, $P$. serotina invaded $P$. sylvestris plantations had $75.8 \%$ more archaeophytes and $25.8 \%$ more neophytes than non-invaded plantations. Similarly, $R$. pseudoacacia forests had $78.6 \%$ more archaeophytes and $15.1 \%$ more neophytes than Quercus-Acer-Tilia forests.

Understory vegetation alpha diversity

We found the highest species richness in $R$. pseudoacacia and non-invaded poor $P$. sylvestris forests and $P$. serotina invaded $P$. sylvestris plantations, while the lowest-in F. sylvatica and Q. rubra forests (Fig. 5, Table 4). Q. rubra forests had almost twice lower number of species than $Q$. petraea and Quercus-Acer- serotina, $Q$. petraea-acidophilous Quercus petraea-dominated forest, $Q$. rubra-Q. rubra dominated forests, Quercus-AcerTilia-Q. petraea, Acer platanoides, A. pseudoplatanus, Tilia cordata dominated fertile forest, Robinia-Robinia pseudoacacia dominated forest), estimated using Poisson GLMMs. Letters denote variants that are not different at $\mathrm{p}=0.05$, according to Tukey posteriori tests. For model details see Table 3

Tilia forests, while $P$. serotina invaded $P$. sylvestris plantations had one-fourth more species than noninvaded. We also found statistically insignificant ( $\mathrm{p}>0.05$ ) but biologically relevant differences: Quercus-Acer-Tilia forests had $15 \%$ fewer species than $R$. pseudoacacia forests, while non-invaded poor $P$. sylvestris forests had $13 \%$ more species than invaded. We found the highest phylogenetic diversity in $R$. pseudoacacia forests and $P$. serotina invaded $P$. sylvestris forests, and the lowest-in $Q$. rubra and $F$. sylvatica forests. We found higher phylogenetic diversity in $Q$. petraea than $Q$. rubra forests and $P$. serotina invaded than non-invaded $P$. sylvestris forests. We also found a statistically insignificant $(p>0.05)$ but biologically relevant difference in phylogenetic diversity, which was $27 \%$ higher in $R$. pseudoacacia than Quercus-Acer-Tilia forests. We 


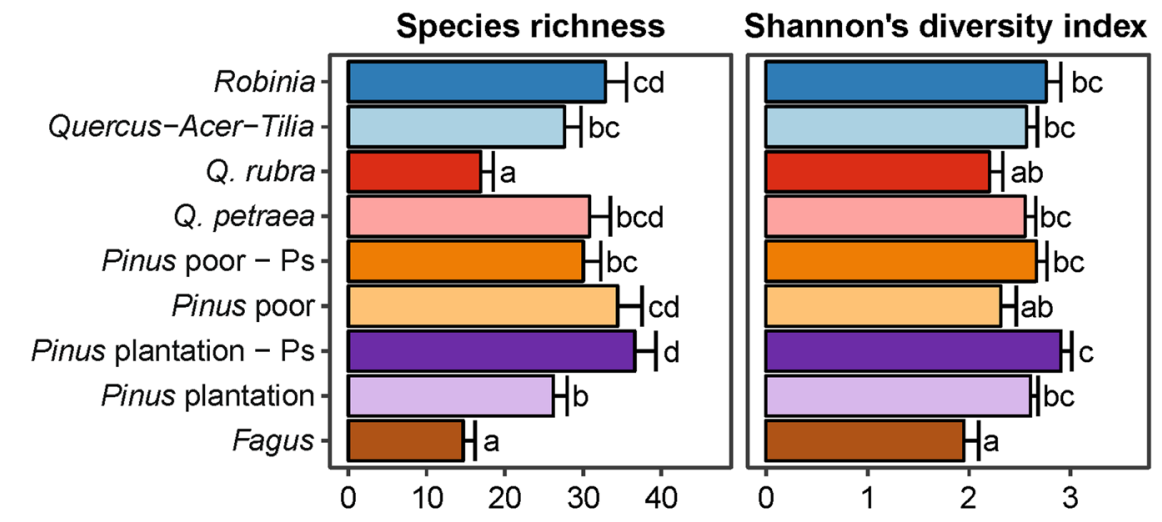

Faith's phylogenetic diversity Mean pairwise distance


Fig. 5 Mean (+ SE) values of alpha diversity indices in forest types studied (Fagus-Fagus sylvatica dominated forest, Pinus plantation-Pinus sylvestris forests in fertile sites, Pinus plantation-PS- $P$. sylvestris plantation invaded by Prunus serotina, Pinus poor- $P$. sylvestris forest in poor sites, Pinus poor-PS- $P$. sylvestris forest in poor sites invaded by $P$. serotina, $Q$. petraeaacidophilous Quercus petraea-dominated forest, $Q$. rubra- $Q$.

revealed similar trends in functional richness, while differences between invaded and non-invaded forest types were higher. We did not find biologically relevant differences between invaded and non-invaded rubra dominated forests, Quercus-Acer-Tilia-Q. petraea, Acer platanoides, A. pseudoplatanus, Tilia cordata dominated fertile forest, Robinia-Robinia pseudoacacia dominated forest). Letters denote variants which are not different at $\mathrm{p}=0.05$, according to Tukey posteriori tests (n.s.-lack of differences between any pair of variants for a particular variable). For model details see Table 4

forests in species diversity, as well as mean pairwise distance and functional dispersion. 
Table 4 Analysis of variance for alpha diversity indices among forest types studied, assessed using linear mixed-effects models (with study plot block as a random intercept)

\begin{tabular}{|c|c|c|c|c|c|c|c|}
\hline Response & Variable & df & Sum of Squares & Mean Square & $\mathrm{F}$ & $\operatorname{Pr}(>\mathrm{F})$ & $\begin{array}{l}\text { Block random effects } \\
\text { SD }\end{array}$ \\
\hline Species richness & $\begin{array}{c}\text { Forest } \\
\text { type }\end{array}$ & 8 & 160.3678 & 20.0460 & 20.046 & $<0.0001$ & 0.265 \\
\hline Shannon diversity index & $\begin{array}{c}\text { Forest } \\
\text { type }\end{array}$ & 8 & 8.2356 & 1.0294 & 5.720 & $<0.0001$ & 0.146 \\
\hline $\begin{array}{l}\text { Faith's phylogenetic } \\
\text { diversity }\end{array}$ & $\begin{array}{c}\text { Forest } \\
\text { type }\end{array}$ & 8 & $17,473,654.8014$ & $2,184,206.8502$ & 10.821 & $<0.0001$ & 286.098 \\
\hline Mean pairwise distance & $\begin{array}{c}\text { Forest } \\
\text { type }\end{array}$ & 8 & $184,069.1143$ & $23,008.6393$ & 3.327 & 0.0014 & 62.986 \\
\hline Functional dispersion & $\begin{array}{c}\text { Forest } \\
\text { type }\end{array}$ & 8 & 0.0086 & 0.0011 & 1.978 & 0.0525 & 0.008 \\
\hline Functional richness & $\begin{array}{c}\text { Forest } \\
\text { type }\end{array}$ & 8 & 0.0003 & 0.0000 & 6.703 & $<0.0001$ & 0.002 \\
\hline
\end{tabular}

Understory vegetation beta diversity

We found the highest taxonomic and phylogenetic beta-diversity in $F$. sylvatica forests and the lowestin $P$. serotina invaded $P$. sylvestris plantations and $R$. pseudoacacia forests (Fig. 6, Table 5). For functional beta diversity we found the highest values in $F$. sylvatica and $Q$. rubra forests, and the lowest-in $P$. serotina invaded $P$. sylvestris plantations. $Q$. rubra forests had higher functional and phylogenetic beta diversity than $Q$. petraea forests due to higher nestedness, while we did not find such a pattern in taxonomic beta diversity. $R$. pseudoacacia forests had lower taxonomic and phylogenetic beta diversity, but similar functional beta diversity as Quercus-AcerTilia forests. Here differences resulted from higher taxonomic and phylogenetic turnover, with the same level of nestedness. $P$. serotina invaded poor $P$. sylvestris forests had lower functional beta diversity than non-invaded poor $P$. sylvestris forests, due to lower nestedness. We did not confirm differences for taxonomic and phylogenetic beta diversity. In contrast, invaded $P$. sylvestris plantations had lower taxonomic, functional and phylogenetic beta diversity than non-invaded $P$. sylvestris plantations. In all cases non-invaded $P$. sylvestris plantations had higher nestedness than invaded ones.

\section{Discussion}

Impacts are mediated by influences of invasive trees on resource availability

Impacts of the invasive tree species studied differed among species and habitats. We found the lowest reduction of alpha diversity and specialists in $Q$. rubra forests, while we found no reduction in R. pseudoacacia forests, compared to mature native forests. In poor $P$. sylvestris forests, $P$. serotina invasion decreased alpha diversity, while in $P$. sylvestris plantations we did not find such a pattern. This may suggest that impacts of invasive trees on understory alpha diversity are more severe where resources are more limiting — such as light in Q. rubra forests and soil nutrients in poor $P$. sylvestris forests. This explains the high consistency among studies revealing negative effects of $Q$. rubra on understory vegetation (Marozas et al. 2009; Woziwoda et al. 2014; Gentili et al. 2019) and some results revealing no impacts (Verheyen et al. 2007; Chabrerie et al. 2010; Gentili et al. 2019) of P. serotina. Moreover, studies reported that $P$. serotina decreased understory plant diversity on less fertile sites resembling poor $P$. sylvestris forests from this study (Godefroid et al. 2005; Halarewicz and Żołnierz 2014). Halarewicz (2012) also found a lower effect size of $P$. serotina impacts on species richness in fertile than in poor $P$. sylvestris forests. Therefore, the reference ecosystem influences 



Phylogenetic nestedness

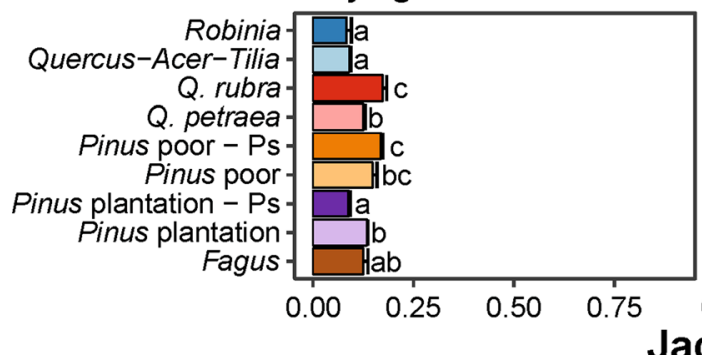

Taxonomic turnover

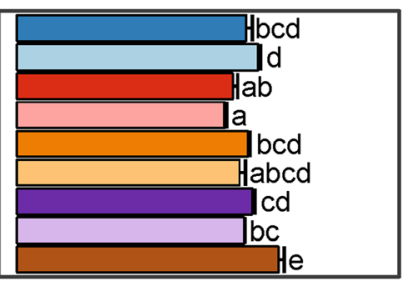

Functional turnover

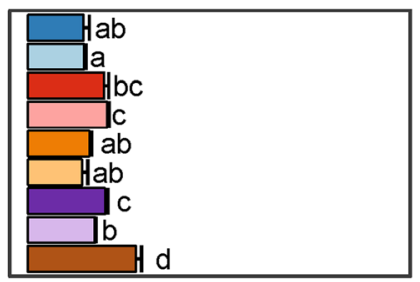

Phylogenetic turnover

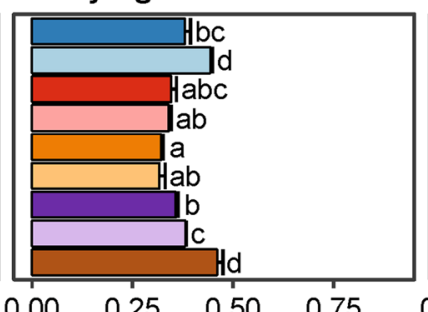

Taxonomic overall

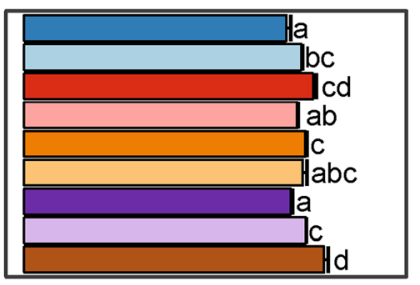

Functional overall

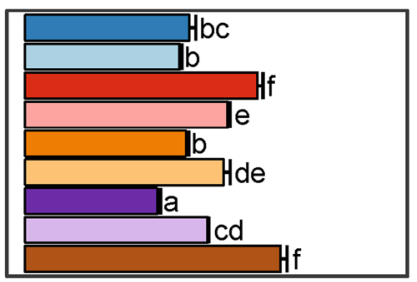

Phylogenetic overall

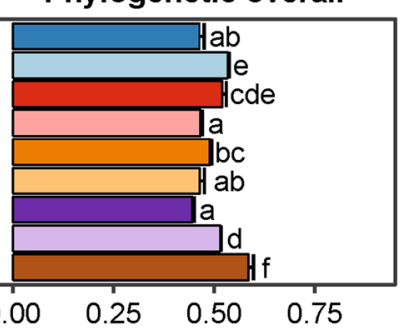

Jaccard's dissimilarity index

Fig. 6 Mean (+ SE) turnover, nestedness and overall beta diversity in forest types studied (Fagus-Fagus sylvatica dominated forest, Pinus plantation-Pinus sylvestris forests in fertile sites, Pinus plantation-PS- $P$. sylvestris plantation invaded by Prunus serotina, Pinus poor-P. sylvestris forest in poor sites, Pinus poor-PS- $P$. sylvestris forest in poor sites invaded by $P$. serotina, $Q$. petraea-acidophilous Quercus petraea-dominated

the effect of $P$. serotina invasion on alpha diversity metrics. In contrast, $R$. pseudoacacia impacts were not due to decreased light availability, but rather due to nitrogen fixation and increased soil nitrogen availability (Rice et al. 2004), resulting in increasing alpha diversity or no impacts, similar to other studies (Sitzia et al. 2012; Hejda et al. 2017; Gentili et al. 2019). However, still other studies revealed decreases of species diversity by $R$. pseudoacacia, in comparison with Betula pendula urban forests (Kowarik et al. 2019), Q. cerris and $Q$. pubescens thermophilous forests (Lazzaro et al. 2018) or shrublands on abandoned fields in China (Kou et al. 2016). Therefore, although our results suggested increased alpha diversity in $R$. pseudoacacia forests, it can only be compared with mature native temperate forests in forest, $Q$. rubra-Q. rubra dominated forests, Quercus-AcerTilia-Q. petraea, Acer platanoides, A. pseudoplatanus, Tilia cordata dominated fertile forest, Robinia-Robinia pseudoacacia dominated forest). Letters denote variants that are not different at $p=0.05$, according to Tukey posteriori tests. For model details see Table 5

Europe, as comparisons with other reference ecosystems (see above) are in contrast.

Eco-evolutionary novelty does not increase impacts of invasive trees

Since Darwin's (1859) observations, numerous theories in invasion ecology assumed that success or impacts of invasive species depend on the phylogenetic or functional similarity of alien and native species (Ricciardi and Atkinson 2004; Enders et al. 2020). Earlier studies revealed higher impacts of alien species less similar to native species (Ricciardi and Atkinson 2004), but impacts of alien species also depend on species quantity in the ecosystems (Kumschick et al. 2015). Alien tree species are more 
Table 5 Analysis of variance for beta diversity indices among forest types studied

\begin{tabular}{|c|c|c|c|c|c|c|}
\hline Response & Variable & $\mathrm{df}$ & Sum of squares & Mean square & F & $\operatorname{Pr}(>\mathrm{F})$ \\
\hline \multirow[t]{2}{*}{ Taxonomic nestedness } & Forest type & 8 & 3.301 & 0.413 & 29.836 & $<0.0001$ \\
\hline & Residuals & 5083 & 70.305 & 0.014 & & \\
\hline \multirow[t]{2}{*}{ Taxonomic turnover } & Forest type & 8 & 3.068 & 0.384 & 19.241 & $<0.0001$ \\
\hline & Residuals & 5083 & 101.318 & 0.020 & & \\
\hline \multirow[t]{2}{*}{ Taxonomic overall } & Forest type & 8 & 1.104 & 0.138 & 13.740 & $<0.0001$ \\
\hline & Residuals & 5083 & 51.042 & 0.010 & & \\
\hline \multirow[t]{2}{*}{ Functional nestedness } & Forest type & 8 & 12.229 & 1.529 & 34.938 & $<0.0001$ \\
\hline & Residuals & 5083 & 222.397 & 0.044 & & \\
\hline \multirow[t]{2}{*}{ Functional turnover } & Forest type & 8 & 2.435 & 0.304 & 16.483 & $<0.0001$ \\
\hline & Residuals & 5083 & 93.878 & 0.018 & & \\
\hline \multirow[t]{2}{*}{ Functional overall } & Forest type & 8 & 16.343 & 2.043 & 86.742 & $<0.0001$ \\
\hline & Residuals & 5083 & 119.712 & 0.024 & & \\
\hline \multirow[t]{2}{*}{ Phylogenetic nestedness } & Forest type & 8 & 2.841 & 0.355 & 29.095 & $<0.0001$ \\
\hline & Residuals & 5083 & 62.040 & 0.012 & & \\
\hline \multirow[t]{2}{*}{ Phylogenetic turnover } & Forest type & 8 & 6.075 & 0.759 & 38.912 & $<0.0001$ \\
\hline & Residuals & 5083 & 99.201 & 0.020 & & \\
\hline \multirow[t]{2}{*}{ Phylogenetic overall } & Forest type & 8 & 4.065 & 0.508 & 41.606 & $<0.0001$ \\
\hline & Residuals & 5083 & 62.073 & 0.012 & & \\
\hline
\end{tabular}

abundant in sites occupied by functionally similar species (Sande et al. 2020). Therefore, both of these contradictory findings could be valid. We expected $R$. pseudoacacia to cause the highest decrease of alpha diversity, compared to mature native forests. In temperate European forests this species is more phylogenetically distinct (no native congenerics, in contrast to $P$. serotina and $Q$. rubra). Its functional distinction is lower-there are functionally similar shrub species (e.g. nitrogen-fixing legume Cytisus scoparius) and tree species which also fix nitrogen (e.g. Alnus glutinosa). Reference to mature forest ecosystems here does not allow conclusions about the effects of $R$. pseudoacacia in early-successional stages, where it can be more functionally and phylogenetically similar to native species. We also expected the lowest impact of $Q$. rubra, which is both phylogenetically and functionally similar to native species ( $Q$. petraea and F. sylvatica). Although biodiversity metrics of $Q$. rubra understory were similar to $F$. sylvatica forests, their composition was more similar to $Q$. petraea and P. sylvestris forests. However, it differed from Quercus-Acer-Tilia forests, similarly as in Central Poland (Woziwoda et al. 2014) and
Lithuania (Marozas et al. 2009). In the case of $P$. serotina we could predict low impacts according to the presence of both phylogenetically related (P. padus, $P$. avium) and functionally similar (e.g. Sorbus aucuparia, Frangula alnus) species. However, we found a decrease of alpha diversity in $P$. serotina invaded forests only in poor $P$. sylvestris forests, where $P$. serotina congenerics do not occur and functionally similar species are sparsely distributed. In contrast, $P$. sylvestris plantations are usually colonized by numerous shrubs, including $P$. avium and $S$. aucuparia, forming dense shrub layers (Zerbe and Wirth 2006). This only partially supports the theory of eco-evolutionary naivety (Ricciardi and Atkinson 2004; Enders et al. 2020). Our results rather showed that influences of alien tree species on biodiversity are mediated by their abundance (Kumschick et al. 2015), which is positively correlated with functional similarity to native species (Sande et al. 2020). 
More alien species in invaded forests-invasional meltdown or biotic acceptance?

We found higher numbers of alien species in $R$. pseudoacacia and $P$. serotina invaded $P$. sylvestris forests than in non-invaded and $Q$. rubra forests. These findings are in line with previous studies, revealing higher or the same alien species richness (e.g. Von Holle et al. 2013; Halarewicz and Żołnierz 2014; Slabejová et al. 2019). The one exception was a study comparing $R$. pseuodoacacia forests with Betula pendula forests in Berlin (Trentanovi et al. 2013). Some variation in the number of alien species may result from the spread of natural regeneration of the invasive tree species studied, which successfully colonized adjacent forests (Dyderski and Jagodziński 2018). Also, among herbaceous species, one of the most widespread is the neophyte Impatiens parviflora, occurring in various types of ecosystems across Central Europe (Chmura 2004; Chmura and Sierka 2007; Godefroid and Koedam 2010). These two phenomena blur the effects of alien species facilitation of secondary invasions, known as invasional meltdown (Simberloff and Von Holle 1999; Simberloff 2006). Higher alien species richness, compared to mature native forests, may be connected with habitat modification-increased nutrient availability by $P$. serotina (Aerts et al. 2017) and $R$. pseudoacacia (Rice et al. 2004), due to high decomposition rate of their leaf litter (Horodecki and Jagodziński 2017). Moreover, $P$. sylvestris plantations are more invasible (Zerbe and Wirth 2006), due to soil acidification (Augusto et al. 2002) and higher light availability, connected with low leaf area per unit of basal area (Dyderski and Jagodziński 2019b). Forest types with high alien species richness were also rich in native species, supporting the biotic acceptance theory (Stohlgren et al. 1999, 2006; Dyderski et al. 2015), and also connected with resource availability.

\section{Biotic homogenization-invasive trees decreased} beta diversity

We found that $R$. pseudoacacia decreased taxonomic and phylogenetic beta diversity, compared to mature native forests. Previous studies showed an increase (Kou et al. 2016), decrease (Šibíková et al. 2019) and no impacts (Sitzia et al. 2012; Trentanovi et al. 2013) of $R$. pseudoacacia on taxonomic beta diversity. Our study is in line with findings from Southern Europe (Šibíková et al. 2019), which also compared $R$. pseudoacacia forests with Quercus-Acer-Tilia forests. Other studies compared effects of $R$. pseudoacacia on other reference ecosystems-e.g. early-successional post-agricultural forests (Sitzia et al. 2012; Kou et al. 2016) or urban forests (Trentanovi et al. 2013). In $P$. sylvestris plantations we confirmed lower taxonomic, functional and phylogenetic beta diversity in $P$. serotina invaded forests. In contrast, in poor $P$. sylvestris forests we found only lower functional beta diversity in invaded than non-invaded forests. Both taxonomic and phylogenetic beta diversity were more driven by species turnover than nestedness. This suggests that the main driver of beta-diversity was the ability to host random elements of species composition rather than the presence of core elements of understory vegetation (Baselga 2010). This may be connected with vegetation continuity (Holeksa and Woźniak 2005; Austin 2013) and suggests low impacts of invasive tree species on individualistic understory plant species responses. However, functional beta diversity was more driven by nestedness than the turnover in all forest types, except $P$. serotina invaded $P$. sylvestris plantations. This indicates that particular forest types host a core of functionally similar understory species, which are different in terms of taxonomic affiliation and evolutionary history. This suggests functional filtering of understory plant species, connected with resource availability.

In contrast to other invasive tree species studied, we found higher values of all beta-diversity metrics in $Q$. rubra forests. High beta diversity of $Q$. rubra forests is connected with high turnover and lack of constant species, similar to $F$. sylvatica forests. These two types are located in the middle part of the ordination space and characterized by low to medium soil fertility and low light availability. These two filters reduce the number of species and their abundance, therefore most of the species are transient from adjacent forests. Thus, low alpha diversity and high species turnover lead to high beta diversity, but low conservation values.

\section{Conclusions}

Our study demonstrated how the three invasive tree species most widespread in European forests affected 
alpha and beta diversity of understory vegetation, in comparison to mature native forests. Due to using mature native forests as reference ecosystems, our conclusions cannot inform impacts in other types of ecosystems invaded by the tree species studied, e.g. shrublands or early-successional forests. We provided the first assessment of all three facets of diversity (taxonomic, functional and phylogenetic) for the species studied, broadening the understanding of invasive tree impacts on plant diversity. We proved that invaded forests differ from non-invaded forests in species composition, but did not always have decreased alpha and beta diversity. Influence on understory vegetation diversity depended on a particular invasive species ability for habitat transformation-we found the highest decrease of alpha diversity in $Q$. rubra forests, with low levels of soil nutrients and light availability, while we found increases or no effects in nutrient-rich $R$. pseudoacacia forests. This also explains the different patterns of $P$. serotina impacts in nutrient-poor and rich $P$. sylvestris forests. Both $P$. serotina and $R$. pseudoacacia decreased beta diversity, compared to mature native forests. Due to the high importance of species turnover in shaping taxonomic and phylogenetic beta diversity and the high importance of nestedness in shaping functional beta diversity, these invasive species probably limited the number of random species shaping the regional pool. In contrast, $Q$. rubra forests had higher beta diversity than mature native forests, due to low alpha diversity and high turnover of species, connected with low resource levels.

Impacts of particular invasive species depended on the reference ecosystem properties, which is a source of inconsistency in previous studies, which usually referred to single native ecosystem types. In our case, we referred to the mature native forest ecosystems, which have naturally low alpha-diversity in comparison to early-successional stages. However, these forests contain rare and specialized species, the decline of which contributes to regional and global biodiversity reduction. In terms of global effects on biodiversity, this impact can be a more important effect of the alien tree species studied than decreases of alpha-diversity metrics.

Acknowledgements We are thankful to the two anonymous Reviewers and Associate Editor for their valuable comments to the earlier versions of the manuscript.
Authors' contributions Conceptualization, M.K.D and A.M.J.; methodology, M.K.D. and A.M.J.; data collection and formal analysis, M.K.D.; data curation, M.K.D.; writingoriginal draft preparation, M.K.D.; writing-review and editing, A.M.J.; supervision, A.M.J.; funding acquisition, M.K.D. and A.M.J.

Funding The study was financed by National Science Centre, Poland, under the project no. 2015/19/N/NZ8/03822 entitled: 'Ecophysiological and ecological determinants of invasiveness of trees and shrubs with the examples of Padus serotina, Quercus rubra and Robinia pseudoacacia'. The study was partially supported by the Institute of Dendrology, Polish Academy of Sciences.

Availability of data and material The datasets analyzed during the current study are available from the corresponding author on reasonable request.

Code availability No custom code was used for analyses, all functions used in data analyses were acknowledged and respective $\mathrm{R}$ packages were cited.

\section{Compliance with ethical standards}

Conflict of interest The authors declare no conflict of interest. The funders had no role in the design of the study; in the collection, analyses, or interpretation of data; in the writing of the manuscript, or in the decision to publish the results.

Consent to participate Not applicable.

Consent for publication Not applicable.

Ethics approval The study was conducted in Wielkopolski National Park under permissions no. 25/2014, 7/2105, 7A/2015, 6/2016, 3/2017 and 3/2018.

Open Access This article is licensed under a Creative Commons Attribution 4.0 International License, which permits use, sharing, adaptation, distribution and reproduction in any medium or format, as long as you give appropriate credit to the original author(s) and the source, provide a link to the Creative Commons licence, and indicate if changes were made. The images or other third party material in this article are included in the article's Creative Commons licence, unless indicated otherwise in a credit line to the material. If material is not included in the article's Creative Commons licence and your intended use is not permitted by statutory regulation or exceeds the permitted use, you will need to obtain permission directly from the copyright holder. To view a copy of this licence, visit http://creativecommons.org/licenses/by/4.0/.

\section{References}

Aerts R, Ewald M, Nicolas M, Piat J, Skowronek S, Lenoir J, Hattab T, Garzón-López CX, Feilhauer H, Schmidtlein S, 
Rocchini D, Decocq G, Somers B, Van De Kerchove R, Denef K, Honnay O (2017) Invasion by the Alien Tree Prunus serotina alters ecosystem functions in a temperate deciduous forest. Front Plant Sci 8:179. https://doi.org/10. 3389/fpls.2017.00179

Augusto L, Ranger J, Binkley D, Rothe A (2002) Impact of several common tree species of European temperate forests on soil fertility. Ann For Sci 59:233-253. https://doi.org/ 10.1051/forest:2002020

Austin MP (2013) Vegetation and environment: discontinuities and continuities. In: van der Maarel E, Franklin J (eds) Vegetation ecology. Wiley, New York, pp 71-106

Barkman JJ, Doing H, Segal S (1964) Kritische Bemerkungen Und Vorschläge Zur Quantitativen Vegetationsanalyse. Acta Botanica Neerlandica 13:394-419. https://doi.org/10. 1111/j.1438-8677.1964.tb00164.x

Baselga A (2010) Partitioning the turnover and nestedness components of beta diversity. Glob Ecol Biogeogr 19:134-143. https://doi.org/10.1111/j.1466-8238.2009. 00490.x

Baselga A, Orme D, Villeger S, Bortoli JD, Leprieur F, Logez M, Henriques-Silva R (2018) Betapart: partitioning beta diversity into turnover and nestedness components. Version 1.5.1. https://cran.r-project.org/web/packages/ betapart/index.html (Accessed 03 Aug 2020)

Bretz F, Hothorn T, Westfall PH (2011) Multiple comparisons using R. CRC Press, Boca Raton

Castro-Díez P, Vaz AS, Silva JS, van Loo M, Alonso Á, Aponte C, Bayón Á, Bellingham PJ, Chiuffo MC, DiManno N, Julian K, Kandert S, Porta NL, Marchante H, Maule HG, Mayfield MM, Metcalfe D, Monteverdi MC, Núñez MA, Ostertag R, Parker IM, Peltzer DA, Potgieter LJ, Raymundo M, Rayome D, Reisman-Berman O, Richardson DM, Roos RE, Saldaña A, Shackleton RT, Torres A, Trudgen M, Urban J, Vicente JR, Vilà M, Ylioja T, Zenni RD, Godoy O (2019) Global effects of non-native tree species on multiple ecosystem services. Biol Rev 94:1477-1501. https://doi.org/10.1111/brv.12511

Chabrerie O, Loinard J, Perrin S, Saguez R, Decocq G (2010) Impact of Prunus serotina invasion on understory functional diversity in a European temperate forest. Biol Invasions 12:1891-1907. https://doi.org/10.1007/s10530009-9599-9

Chmura D (2004) Penetration and naturalisation of invasive alien plant species (neophytes) in woodlands of the Silesian Upland (southern Poland). Nature Conservation 60:3-11

Chmura D, Sierka E (2007) The invasibility of deciduous forest communities after disturbance: a case study of Carex brizoides and Impatiens parviflora invasion. For Ecol Manag 242:487-495. https://doi.org/10.1016/j.foreco.2007.01. 083

Cierjacks A, Kowarik I, Joshi J, Hempel S, Ristow M, von der Lippe M, Weber E (2013) Biological Flora of the British Isles: Robinia pseudoacacia. J Ecol 101:1623-1640. https://doi.org/10.1111/1365-2745.12162

Corenblit D, Steiger J, Tabacchi E, González E, Planty-Tabacchi A-M (2014) Ecosystem engineers modulate exotic invasions in riparian plant communities by modifying hydrogeomorphic connectivity: Ecosystem engineers modulate exotic invasions. River Res Appl 30:45-59. https://doi.org/10.1002/rra.2618
Darwin C (1859) On the origin of species by means of natural selection, or the preservation of favoured races in the struggle for life. John Murray, London

Davis MA, Grime JP, Thompson K (2000) Fluctuating resources in plant communities: a general theory of invasibility. J Ecol 88:528-534. https://doi.org/10.1046/j.1365-2745. 2000.00473.x

Diniz-Filho JAF, Sant'Ana CER, Bini LM (1998) An eigenvector method for estimating phylogenetic inertia. Evolution 52:1247-1262. https://doi.org/10.1111/j.1558-5646. 1998.tb02006.x

Dobrylovská D (2001) Litter decomposition of red oak, larch and lime tree and its effect on selected soil characteristics. J For Sci 47:477-485

Dyderski MK, Jagodziński AM (2018) Drivers of invasive tree and shrub natural regeneration in temperate forests. Biol Invasions 20:2363-2379. https://doi.org/10.1007/s10530018-1706-3

Dyderski MK, Jagodziński AM (2019a) Context-dependence of urban forest vegetation invasion level and alien species' ecological success. Forests 10:26. https://doi.org/10.3390/ f10010026

Dyderski MK, Jagodziński AM (2019b) Similar impacts of alien and native tree species on understory light availability in a temperate forest. Forests 10:951. https://doi.org/10.3390/ f10110951

Dyderski MK, Jagodziński AM (2019c) Seedling survival of Prunus serotina Ehrh., Quercus rubra L. and Robinia pseudoacacia L. in temperate forests of Western Poland. For Ecol Manag 450:117498. https://doi.org/10.1016/j. foreco.2019.117498

Dyderski MK, Jagodziński AM (2020) Impact of invasive tree species on natural regeneration species composition, diversity, and density. Forests 11:456. https://doi.org/10. 3390/f11040456

Dyderski MK, Gdula AK, Jagodziński AM (2015) “The rich get richer" concept in riparian woody species-a case study of the Warta River Valley (Poznań, Poland). Urban For Urban Green 14:107-114. https://doi.org/10.1016/j.ufug.2014.12. 003

Dyderski MK, Tyborski J, Jagodziński AM (2017) The utility of ancient forest indicator species in urban environments: a case study from Poznań, Poland. Urban For Urban Green 27:76-83. https://doi.org/10.1016/j.ufug.2017.06.016

Dyderski MK, Chmura D, Dylewski Ł, Horodecki P, Jagodzinski AM, Pietras M, Robakowski P, Woziwoda B (2020) Biological flora of the British Isles: Quercus rubra. J Ecol 108:1199-1225. https://doi.org/10.1111/1365-2745. 13375

Dzwonko Z, Loster S (2001) Wskaźnikowe gatunki roślin starych lasów i ich znaczenie dla ochrony przyrody i kartografii roślinności. Prace Geograficzne 178:119-132

Ellenberg H, Leuschner C (2010) Vegetation Mitteleuropas mit den Alpen in ökologischer, dynamischer und historischer Sicht. UTB, Stuttgart

Enders M, Havemann F, Ruland F, Bernard-Verdier M, Catford JA, Gómez-Aparicio L, Haider S, Heger T, Kueffer C, Kühn I, Meyerson LA, Musseau C, Novoa A, Ricciardi A, Sagouis A, Schittko C, Strayer DL, Vilà M, Essl F, Hulme PE, van Kleunen M, Kumschick S, Lockwood JL, Mabey AL, McGeoch MA, Palma E, Pyšek P, Saul W-C, Yannelli 
FA, Jeschke JM (2020) A conceptual map of invasion biology: integrating hypotheses into a consensus network. Glob Ecol Biogeogr 29:978-991. https://doi.org/10.1111/ geb. 13082

Enquist BJ, Condit R, Peet RK, Schildhauer M, Thiers BM (2016) Cyberinfrastructure for an integrated botanical information network to investigate the ecological impacts of global climate change on plant biodiversity. Peer J Preprints 4:e2615v2. https://doi.org/10.7287/peerj. preprints. $2615 \mathrm{v} 2$

GBIF (2019) Global Biodiversity Information Facility.http:// www.gbif.org/ (Accessed 03 Aug 2020)

Gentili R, Ferrè C, Cardarelli E, Montagnani C, Bogliani G, Citterio S, Comolli R (2019) Comparing negative impacts of Prunus serotina, Quercus rubra and Robinia pseudoacacia on native forest ecosystems. Forests 10:842. https:// doi.org/10.3390/f10100842

Godefroid S, Koedam N (2010) Comparative ecology and coexistence of introduced and native congeneric forest herbs: Impatiens parviflora and I. noli-tangere. Plant Ecol Evol 143:119-127. https://doi.org/10.5091/plecevo.2010. 397

Godefroid S, Phartyal SS, Weyembergh G, Koedam N (2005) Ecological factors controlling the abundance of non-native invasive black cherry (Prunus serotina) in deciduous forest understory in Belgium. For Ecol Manag 210:91-105. https://doi.org/10.1016/j.foreco.2005.02.024

Halarewicz A (2012) Właściwości ekologiczne i skutki rozprzestrzeniania się czeremchy amerykańskiej Padus serotina (Ehrh.) Borkh. w wybranych fitocenozach leśnych. Wydawnictwo Uniwersytetu Przyrodniczego, Wrocław

Halarewicz A, Żołnierz L (2014) Changes in the understorey of mixed coniferous forest plant communities dominated by the American black cherry (Prunus serotina Ehrh.). For Ecol Manage 313:91-97. https://doi.org/10.1023/A: 1023208215796

Hartig F (2020) DHARMa: residual diagnostics for hierarchical (Multi-Level/Mixed) regression models. R package, version 0.2.7. https://cran.r-project.org/web/packages/ DHARMa/index.html (Accessed 03 Aug 2020)

Hejda M, Hanzelka J, Kadlec T, Štrobl M, Pyšek P, Reif J (2017) Impacts of an invasive tree across trophic levels: species richness, community composition and resident species' traits. Divers Distrib 23:997-1007. https://doi.org/10. 1111/ddi.12596

Hill MO, Gauch HG (1980) Detrended correspondence analysis: an improved ordination technique. Vegetatio 42:47-58. https://doi.org/10.1007/BF00048870

Holeksa J, Woźniak G (2005) Biased vegetation patterns and detection of vegetation changes using phytosociological databases. A case study in the forests of the Babia Gora National Park (the West Carpathians, Poland). Phytocoenologia 35:1-18

Horodecki P, Jagodziński AM (2017) Tree species effects on litter decomposition in pure stands on afforested postmining sites. For Ecol Manag 406:1-11. https://doi.org/10. 1016/j.foreco.2017.09.059

Jagodziński AM, Dyderski MK, Horodecki P, Knight KS, Rawlik K, Szmyt J (2019) Light and propagule pressure affect invasion intensity of Prunus serotina in a 14-tree species forest common garden experiment. NeoBiota 46:1-21. https://doi.org/10.3897/neobiota.46.30413

Jin Y, Qian H (2019) V.PhyloMaker: an R package that can generate very large phylogenies for vascular plants. Ecography 42:1353-1359. https://doi.org/10.1111/ecog. 04434

Kleyer M, Bekker RM, Knevel IC, Bakker JP, Thompson K, Sonnenschein M, Poschlod P, Van Groenendael JM, Klimeš L, Klimešová J, Klotz S, Rusch GM, Hermy M, Adriaens D, Boedelthje G, Bossuyt B, Dannemann A, Endels P, Götzenberger L, Hodgson JG, Jackel A-K, Kühn I, Kunzmann D, Ozinga WA, Römermann C, Stadler M, Schlegelmilch M, Steendam HJ, Teckenberg O, Wilmann B, Cornelissen JH, Eriksson O, Garnier E, Peco B (2008) The LEDA Traitbase: a database of life-history traits of the Northwest European flora. J Ecol 96:1266-1274. https:// doi.org/10.1111/j.1365-2745.2008.01430.x

Klotz S, Kühn I, Durka W (2002) BIOLFLOR-Eine Datenbank zu biologisch-ökologischen Merkmalen der Gefäßpflanzen in Deutschland. Schriftenreihe für Vegetationskunde, Bundesamt für Naturschutz, Bonn

Kou M, Garcia-Fayos P, Hu S, Jiao J (2016) The effect of Robinia pseudoacacia afforestation on soil and vegetation properties in the Loess Plateau (China): a chronosequence approach. For Ecol Manag 375:146-158. https://doi.org/ 10.1016/j.foreco.2016.05.025

Kowarik I, Hiller A, Planchuelo G, Seitz B, von der Lippe M, Buchholz S (2019) Emerging urban forests: opportunities for promoting the wild side of the urban green infrastructure. Sustainability 11:6318. https://doi.org/10.3390/ su11226318

Kumschick S, Gaertner M, Vilà M, Essl F, Jeschke JM, Pyšek P, Ricciardi A, Bacher S, Blackburn TM, Dick JTA, Evans T, Hulme PE, Kühn I, Mrugała A, Pergl J, Rabitsch W, Richardson DM, Sendek A, Winter M (2015) Ecological impacts of alien species: quantification, scope, caveats, and recommendations. Bioscience 65:55-63

Laliberté E, Legendre P (2010) A distance-based framework for measuring functional diversity from multiple traits. Ecology 91:299-305. https://doi.org/10.1890/08-2244.1

Laliberté E, Legendre P, Shipley B (2014) FD: measuring functional diversity (FD) from multiple traits, and other tools for functional ecology. https://cran.r-project.org/web/ packages/FD (Accessed 03 Aug 2020)

Lazzaro L, Mazza G, d'Errico G, Fabiani A, Giuliani C, Inghilesi AF, Lagomarsino A, Landi S, Lastrucci L, Pastorelli R, Roversi PF, Torrini G, Tricarico E, Foggi B (2018) How ecosystems change following invasion by Robinia pseudoacacia: Insights from soil chemical properties and soil microbial, nematode, microarthropod and plant communities. Sci Total Environ 622-623:1509-1518. https://doi.org/10.1016/j.scitotenv. 2017.10.017

Lepš J, Hadincová V (1992) How reliable are our vegetation analyses? J Veg Sci 3:119-124. https://doi.org/10.2307/ 3236006

Lonsdale WM (1999) Global patterns of plant invasions and the concept of invasibility. Ecology 80:1522-1536

Mack RN, Simberloff D, Mark Lonsdale W, Evans H, Clout M, Bazzaz FA (2000) Biotic invasions: causes, epidemiology, global consequences, and control. Ecol Appl 10:689-710 
Marozas V, Straigyte L, Sepetiene J (2009) Comparative analysis of Alien Red Oak (Quercus rubra L.) and native common Oak (Quercus robur L.) vegetation in Lithuania. Acta Biologica Universitatis Daugavpiliensis 9:19-24

Mason NWH, Mouillot D, Lee WG, Wilson JB (2005) Functional richness, functional evenness and functional divergence: the primary components of functional diversity. Oikos 111:112-118. https://doi.org/10.1111/j.0030-1299. 2005.13886.x

Montecchiari S, Tesei G, Allegrezza M (2020) Effects of Robinia pseudoacacia $<$ coverage on diversity and environmental conditions of central-northern Italian Quercus pubescens sub-Mediterranean forests (habitat code 91AA*): a threshold assessment. Annali di Botanica 10:33-54. https://doi.org/10.13133/2239-3129/16447

Muys B, Maddelein D, Lust N (1992) Ecology, practice and policy of black cherry (Prunus serotina Ehrh.) management in Belgium. Silva Gandavensis 57:28-45

Oksanen J, Blanchet FG, Kindt R, Legendre P, Michin PR, O'Hara RB, Simpson GL, Solymos P, Henry M, Stevens H, Wagner H (2018) “vegan" 2.3.3.-Community Ecology Package. https://cran.r-project.org/web/packages/vegan/ index.html (Accessed 03 Aug 2020)

Olden JD, Comte L, Giam X (2018) The Homogocene: a research prospectus for the study of biotic homogenisation. NeoBiota 37:23-36. https://doi.org/10.3897/neobiota.37. 22552

Orczewska A (2009) The impact of former agriculture on habitat conditions and distribution patterns of ancient woodland plant species in recent black alder (Alnus glutinosa (L.) Gaertn.) woods in south-western Poland. For Ecol Manag 258:794-803. https://doi.org/10.1016/j.foreco.2009.05. 021

Pearse IS, Sofaer HR, Zaya DN, Spyreas G (2019) Non-native plants have greater impacts because of differing per-capita effects and nonlinear abundance-impact curves. Ecol Lett 22:1214-1220. https://doi.org/10.1111/ele.13284

Penone C, Davidson AD, Shoemaker KT, Di Marco M, Rondinini C, Brooks TM, Young BE, Graham CH, Costa GC (2014) Imputation of missing data in life-history trait datasets: which approach performs the best? Methods Ecol Evol 5:961-970. https://doi.org/10.1111/2041-210X. 12232

Peterken GF (1974) A method for assessing woodland flora for conservation using indicator species. Biol Cons 6:239-245. https://doi.org/10.1016/0006-3207(74)90001-9

Piwczyński M, Puchałka R, Ulrich W (2016) Influence of tree plantations on the phylogenetic structure of understorey plant communities. For Ecol Manag 376:231-237. https:// doi.org/10.1016/j.foreco.2016.06.011

Pla L, Casanoves F, Di Rienzo J (2011) Quantifying functional biodiversity. Springer, Dordrecht

Pyšek P, Manceur AM, Alba C, McGregor KF, Pergl J, Štajerová K, Chytrý M, Danihelka J, Kartesz J, Klimešová J, Lučanová M, Moravcová L, Nishino M, Sádlo J, Suda J, Tichý L, Kühn I (2015) Naturalization of central European plants in North America: species traits, habitats, propagule pressure, residence time. Ecology 96:762-774. https://doi. org/10.1890/14-1005.1
R Core Team (2019) R: A language and environment for statistical computing. R Foundation for Statistical Computing, Vienna

Ratyńska H, Wojterska M, Brzeg A, Kołacz M (2010) Multimedialna encyklopedia zbiorowisk roślinnych Polski. NFOSiGW, UKW

Ricciardi A, Atkinson SK (2004) Distinctiveness magnifies the impact of biological invaders in aquatic ecosystems. Ecol Lett 7:781-784. https://doi.org/10.1111/j.1461-0248.2004. 00642.x

Rice SK, Westerman B, Federici R (2004) Impacts of the exotic, nitrogen-fixing black locust (Robinia pseudoacacia) on nitrogen-cycling in a pine-Oak ecosystem. Plant Ecol 174:97-107. https://doi.org/10.1023/B:VEGE. $0000046049.21900 .5 \mathrm{a}$

Richardson DM (1998) Forestry trees as invasive aliens. Conserv Biol 12:18-26. https://doi.org/10.1111/j.1523-1739. 1998.96392.x

Sande MT, Bruelheide H, Dawson W, Dengler J, Essl F, Field R, Haider S, Kleunen M, Kreft H, Pagel J, Pergl J, Purschke O, Pyšek P, Weigelt P, Winter M, Attorre F, Aubin I, Bergmeier E, Chytrý M, Dainese M, De Sanctis M, Fagundez J, Golub V, Guerin GR, Gutiérrez AG, Jandt U, Jansen F, Jiménez-Alfaro B, Kattge J, Kearsley E, Klotz S, Kramer K, Moretti M, Niinemets Ü, Peet RK, Penuelas J, Petř́k P, Reich PB, Sandel B, Schmidt M, Sibikova M, Violle C, Whitfeld TJS, Wohlgemuth T, Knight TM (2020) Similar factors underlie tree abundance in forests in native and alien ranges. Glob Ecol Biogeogr 29:281-294. https://doi. org/10.1111/geb.13027

Santos T (2018) PVR: phylogenetic eigenvectors regression and phylogentic signal-representation curve. https://cran.rproject.org/web/packages/PVR/ (Accessed 03 Aug 2020)

Sapsford SJ, Brandt AJ, Davis KT, Peralta G, Dickie IA, Gibson RD, Green JL, Hulme PE, Nuñez MA, Orwin KH, Pauchard A, Wardle DA, Peltzer DA (2020) Towards a framework for understanding the context-dependence of impacts of non-native tree species. Funct Ecol 34:944-955. https://doi.org/10.1111/1365-2435.13544

Seebens H, Clarke DA, Groom Q, Wilson JRU, García-Berthou E, Kühn I, Roigé M, Pagad S, Essl F, Vicente J, Winter M, McGeoch M (2020) A workflow for standardising and integrating alien species distribution data. NeoBiota 59:39-59. https://doi.org/10.3897/neobiota.59.53578

Šibíková M, Jarolímek I, Hegedüšová K, Májeková J, Mikulová K, Slabejová D, Škodová I, Zaliberová M, Medvecká J (2019) Effect of planting alien Robinia pseudoacacia trees on homogenization of Central European forest vegetation. Sci Total Environ 687:1164-1175. https://doi.org/10.1016/ j.scitotenv.2019.06.043

Simberloff D (2006) Invasional meltdown 6 years later: important phenomenon, unfortunate metaphor, or both? Ecol Lett 9:912-919. https://doi.org/10.1111/j.1461-0248. 2006.00939.x

Simberloff D, Von Holle B (1999) Positive interactions of nonindigenous species: invasional meltdown? Biol Invasions 1:21-32. https://doi.org/10.1023/A:1010086329619

Sitzia T, Campagnaro T, Dainese M, Cierjacks A (2012) Plant species diversity in alien black locust stands: a paired comparison with native stands across a north- 
Mediterranean range expansion. For Ecol Manage 285:85-91. https://doi.org/10.1016/j.foreco.2012.08.016

Slabejová D, Bacigál T, Hegedüšová K, Májeková J, Medvecká J, Mikulová K, Šibíková M, Škodová I, Zaliberová M, Jarolímek I (2019) Comparison of the understory vegetation of native forests and adjacent Robinia pseudoacacia plantations in the Carpathian-Pannonian region. For Ecol Manage 439:28-40. https://doi.org/10.1016/j.foreco.2019. 02.039

Starfinger U, Kowarik I, Rode M, Schepker H (2003) From desirable ornamental plant to pest to accepted addition to the flora? - the perception of an alien tree species through the centuries. Biol Invasions 5:323-335. https://doi.org/10. 1023/B:BINV.0000005573.14800.07

Staska B, Essl F, Samimi C (2014) Density and age of invasive Robinia pseudoacacia modulate its impact on floodplain forests. Basic Appl Ecol 15:551-558. https://doi.org/10. 1016/j.baae.2014.07.010

Stekhoven DJ, Bühlmann P (2012) MissForest-non-parametric missing value imputation for mixed-type data. Bioinformatics 28:112-118. https://doi.org/10.1093/ bioinformatics/btr597

Stohlgren TJ, Binkley D, Chong GW, Kalkhan MA, Schell LD, Bull KA, Otsuki Y, Newman G, Bashkin M, Son Y (1999) Exotic plant species invade hot spots of native plant diversity. Ecol Monogr 69:25-46

Stohlgren TJ, Jarnevich C, Chong GW, Evangelista PH, Pyšek P, Kaplan Z, Richardson DM (2006) Scale and plant invasions: a theory of biotic acceptance. Preslia 78:405-426

Terwei A, Zerbe S, Mölder I, Annighöfer P, Kawaletz H, Ammer C (2016) Response of floodplain understorey species to environmental gradients and tree invasion: a functional trait perspective. Biol Invasions 18:2951-2973. https://doi.org/10.1007/s10530-016-1188-0

Tokarska-Guzik B, Dajdok Z, Zając M, Zając A, Urbisz A, Danielewicz W, Hołdyński C (2012) Rośliny obcego pochodzenia w Polsce ze szczególnym uwzględnieniem gatunków inwazyjnych. Generalna Dyrekcja Ochrony Środowiska, Warszawa

Trentanovi G, von der Lippe M, Sitzia T, Ziechmann U, Kowarik I, Cierjacks A (2013) Biotic homogenization at the community scale: disentangling the roles of urbanization and plant invasion. Divers Distrib 19:738-748. https:// doi.org/10.1111/ddi.12028

Tsirogiannis C, Sandel B (2016) PhyloMeasures: a package for computing phylogenetic biodiversity measures and their statistical moments. Ecography 39:709-714. https://doi. org/10.1111/ecog.01814

Verheyen K, Vanhellemont M, Stock T, Hermy M (2007) Predicting patterns of invasion by black cherry (Prunus serotina Ehrh.) in Flanders (Belgium) and its impact on the forest understorey community. Divers Distrib 13:487-497. https://doi.org/10.1111/j.1472-4642.2007.00334.x

Verheyen K, Bažány M, Chećko E, Chudomelová M, ClossetKopp D, Czortek P, Decocq G, Frenne PD, Keersmaeker
LD, García CE, Fabšičová M, Grytnes J-A, Hederová L, Hédl R, Heinken T, Schei FH, Horváth S, Jaroszewicz B, Jermakowicz E, Klinerová T, Kolk J, Kopecký M, Kuras I, Lenoir J, Macek M, Máliš F, Martinessen TC, Naaf T, Papp L, Papp-Szakály Á, Pech P, Petř́k P, Prach J, Reczyńska K, Sætersdal M, Spicher F, Standovár T, Świerkosz K, Szczęśniak E, Tóth Z, Ujházy K, Ujházyová M, Vangansbeke P, Vild O, Wołkowycki D, Wulf M, Baeten L (2018) Observer and relocation errors matter in resurveys of historical vegetation plots. J Veg Sci 29:812-823. https://doi.org/10.1111/jvs.12673

Vilà M, Espinar JL, Hejda M, Hulme PE, Jarošík V, Maron JL, Pergl J, Schaffner U, Sun Y, Pyšek P (2011) Ecological impacts of invasive alien plants: a meta-analysis of their effects on species, communities and ecosystems. Ecol Lett 14:702-708. https://doi.org/10.1111/j.1461-0248.2011. 01628.x

Von Holle B, Neill C, Largay EF, Budreski KA, Ozimec B, Clark SA, Lee K (2013) Ecosystem legacy of the introduced N2-fixing tree Robinia pseudoacacia in a coastal forest. Oecologia 172:915-924. https://doi.org/10.1007/ s00442-012-2543-1

Wagner V, Chytrý M, Jiménez-Alfaro B, Pergl J, Hennekens S, Biurrun I, Knollová I, Berg C, Vassilev K, Rodwell JS, Škvorc Ž, Jandt U, Ewald J, Jansen F, Tsiripidis I, BottaDukát Z, Casella L, Attorre F, Rašomavičius V, Ćušterevska R, Schaminée JHJ, Brunet J, Lenoir J, Svenning J-C, Kącki Z, Petrášová-Šibíková M, Šilc U, García-Mijangos I, Campos JA, Fernández-González F, Wohlgemuth T, Onyshchenko V, Pyšek P (2017) Alien plant invasions in European woodlands. Divers Distrib 23:969-981. https:// doi.org/10.1111/ddi.12592

Wild J, Kaplan Z, Danihelka J, Petřík P, Chytrý M, Novotný P, Rohn M, Šulc V, Brůna J, Chobot K, Ekrt L, Holubová D, Knollová I, Kocián P, Štech M, Štěpánek J, Zouhar V (2019) Plant distribution data for the Czech Republic integrated in the Pladias database. Preslia 91:1-24. https:// doi.org/10.23855/preslia.2019.001

Woziwoda B, Kopeć D, Witkowski J (2014) The negative impact of intentionally introduced Quercus rubra L. on a forest community. Acta Soc Bot Pol 83:39-49. https://doi. org/10.5586/asbp.2013.035

Woziwoda B, Dyderski MK, Kobus S, Parzych A, Jagodziński AM (2019) Natural regeneration and recruitment of native Quercus robur and introduced Q. rubra in European oakpine mixed forests. For Ecol Manag 449:117473. https:// doi.org/10.1016/j.foreco.2019.117473

Zerbe S, Wirth P (2006) Non-indigenous plant species and their ecological range in Central European pine (Pinus sylvestris L.) forests. Ann For Sci 63:189-203. https://doi.org/10. 1051/forest:2005111

Publisher's Note Springer Nature remains neutral with regard to jurisdictional claims in published maps and institutional affiliations. 